\title{
Development of Learning Media of Microscope Portable Auto Design to Increase Student's Problem- Solving Ability in Light and Optical Tools Topic
}

\author{
Aris Doyan*, A. Wahab Jufri, Susilawati, A. Hardiyansyah, K. Auliya, S. Hakim, L. Muliyadi \\ Master of Science Education Study Program \\ University of Mataram \\ West Nusa Tenggara, Indonesia \\ *aris_doyan@unram.ac.id, susilawatihambali@unram.ac.id, adihardiyansyah1991@gmail.com
}

\begin{abstract}
This study aims to evaluate the effectiveness of developed learning media in the form of digital portable auto design microscopes to improve student's problem-solving abilities. This research used a research and development method. The subjects of this study were students of grade VIII at one of private junior high school in Mataram. The main products includes portable digital auto design microscopes and supporting devices in the form of syllabus, lesson plan, worksheet, and instruments of problem-solving abilities developed with learning models of Problem Based Learning. To find out the effectiveness of the product, the data of student's problem-solving ability was then analyzed using the $\mathrm{N}$-Gain equation. The results showed that the portable digital microscope auto design is very effective for problem-solving capabilities with a gain value of 0.71 .
\end{abstract}

Keywords: microscope digital portable auto design, problemsolving ability

\section{INTRODUCTION}

Based on the pre-eliminary reserach in one of the Islamic Middle School in Mataram, it was found that there was a tendency for students to consider science as difficult and abstract subjects. Moreover, the lack of learning media and practicum tools in the schools were observed. The ability of teachers to implement learning strategies that seem monotonous was also one factor, where learning activities were not enriched with the new things. It was also observed that students were not actively involved in the learning activities, resulted in the students only accept and memorize lessons without connecting the knowledge gained and its application in real life [1].

One of the basic competencies contained in science learning is light and optical devices. Light material and optical devices still need an attention, including concrete media to demonstrate the function and use of lenses and mirrors. Teachers are required to have media and strategies in creating active and effective learning as well as having the right strategy to teach the material so that students can solve problems.

\section{METHODS}

This research was a research and development study using the Dick and Carey development model [2]. The product developed was a portable auto design digital microscope learning media to improve the problem-solving ability of students of grade VIII at junior high school in the topic of light material and optical devices.

The components of the development design of Dick and Carey are as follows [3]: (1) analysis of the need to set goals, (2) conduct analysis of learning, (3) analysis of learners and their environment, (4) formulate specific learning goals, (5) developing assessment instruments, (6) developing learning strategies, (7) developing and selecting learning materials, (8) design and develop formative evaluation, (9) revise learning, (10) design and develop a summative evaluation. In this recent study, the evaluation of the developed product was conducted.

\section{Results AND DiscussiON}

Validation test of learning media of the portable digital auto microscope design has been done. The result showed that the products have valid characteristics with a category very suitable for use, very practical, and very effective in improving the student's problem-solving ability [1]. To see the effectiveness of the media to improve the ability of students to solve problems, the evaluation test was perfomed. The ability to solve problems has four indicators consisting of (1) understanding the problem, (2) planning a solution, (3) solving the problem, and (4) re-checking the solution [4].

The results of the analysis of problem-solving ability tests can be seen in Fig 1. It can be seen that there is a very significant increase between pre-test scores and post-test scores for students in the Abu Hurairah man and women of Mataram Islamic Middle School (Fig 1). This shows that portable digital microscope auto design is effective to improve students' problem-solving abilities. The effectiveness of the use of a portable digital auto design microscope is also shown in the NGain chart (Fig 2). 


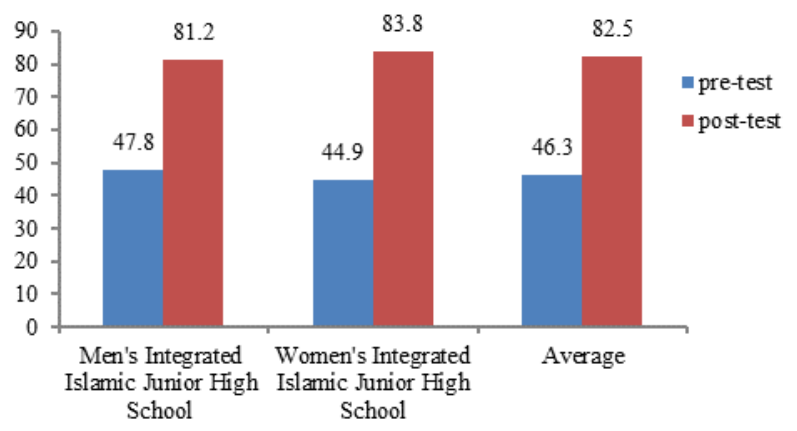

Fig. 1. Graph of pre-test and post-test value of problem solving capabilities.

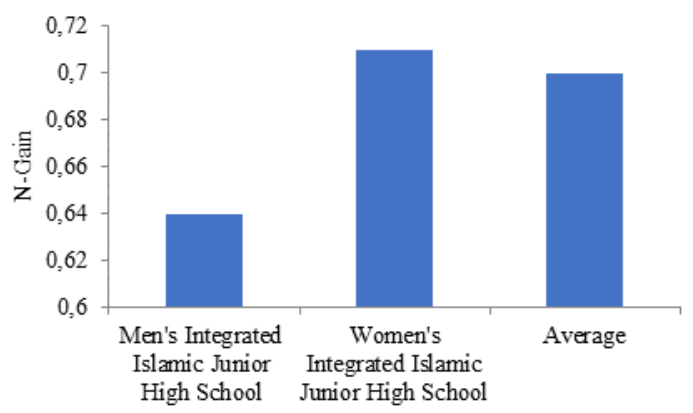

Fig. 2. Graphs of N-Gain Problem-Solving Capabilities.

Figure 2 shows that the problem-solving ability of the two schools is in the medium category because the N-Gain scores obtained are 0.64 and 0.71 . This value is in the range of 0.3 to 0.7 according to the N-Gain Table, so this range is in the medium criteria for the Integrated Islamic Middle School for men and Higher for the Integrated Islamic Middle School for women.

Improvement of each indicator of problem-solving ability can be seen in the Table 1. It can be seen that there is an increase in pre-test and post-test values which were analyzed using N-Gain. The data above shows that there are significant differences between the pre-test and post-test scores for each indicator of problem-solving ability. The improvement of each indicator of problem ability in each school as a whole is in the medium and high categories.

TABLE I. TABLE STYLES AVERAGE N-GAin FOR EACH INDICATOR OF PROBLEM SOLVING ABILITY

\begin{tabular}{|l|l|l|l|l|}
\hline \multirow{2}{*}{$\begin{array}{c}\text { Integrated } \\
\text { Islamic } \\
\begin{array}{c}\text { Middle } \\
\text { School }\end{array}\end{array}$} & $\begin{array}{c}\text { Understand } \\
\text { the Problem }\end{array}$ & $\begin{array}{c}\text { Planning for } \\
\text { Completion }\end{array}$ & $\begin{array}{c}\text { Solve the } \\
\text { problem }\end{array}$ & $\begin{array}{c}\text { Check } \\
\text { again }\end{array}$ \\
\cline { 2 - 5 } Men & 0.62 & 0.79 & 0.53 & 0.43 \\
\hline Women & 0.81 & 0.69 & 0.58 & 0.49 \\
\hline Average & 0.72 & 0.74 & 0.56 & 0.46 \\
\hline
\end{tabular}

For the indicator of understand the problem, the N-gain scores for men's and women's integrated Islamic junior high school were 0.62 in the medium category and 0.81 in the high category, respectivelly. This shows that the media and learning tools developed are effective in improving students' problem- solving abilities on indicators of understanding problems. This indicator requires students to be able to define the amount mentioned in the problem. For example, students can provide definitions by writing down quantities known in the problem such as object distance, shadow distance, object height, focus distance, the magnification of the shadows mentioned. Reference [5] states that the use of media in learning can influence the improvement of students' problem-solving abilities. In addition to the media, the use of learning models also influences the problem-solving ability [6]. This opinion is reinforced by Jamuri [7] which states that teaching by giving problems will make students more skilled in understanding the problem before finding a solution.

The second indicator of planning for completion obtained an $\mathrm{N}$-Gain value of 0.79 with a high category for men's Integrated Islamic Junior High School and 0.69 with a moderate category for women's Integrated Islamic Junior High School. Students will be able to think of problem solutions if they already understand the problem well [8]. Besides, Cilder [9] said that the settlement planning process is directly proportional to the level of understanding of the problem given. Skilled learners will be able to connect directly the concepts they have understood and the completion steps they will take can be in the form of descriptions or numerical operations [10].

The third indicator, which is solving the problem, obtained an average $\mathrm{N}$-Gain value of 0.53 in the medium category for men's integrated Islamic junior high school and 0.58 in the medium category for women's integrated Islamic junior high school. This shows students have been able to solve the problem given by the numerical operations needed, only there was a mistake in calculating the results. Reference [11] states that the problem-solving ability of students is not only seen from 1 or 2 indicators, but the most important is how students can solve problems as planned. Reference [12] states that students who can understand problems will also be able to solve problems, but some students are less able to apply numerical concepts correctly and critically in solving problems.

The fourth indicator is to re-examine the process and results. The average $\mathrm{N}$-gain value of this indicator was obtained 0.46 for the Integrated Islamic Middle School for men and 0.49 for the Integrated Islamic Middle School for women with a moderate category for both schools. This value compared to the other 3 indicators was the lowest. Indicators of re-examine this process is an indicator that requires students to re-examine the process and the results of problem-solving. Reference [13] states that in solving problems, comprehensive knowledge is needed to be able to solve problems completely and correctly. Besides, problem-solving is not only enough to memorize the formulas or equations used, but also clarify the purpose of problem-solving [14] so that it can be understood that science does not only lie in mastering abstract formulas and equations but is a combination of mathematical concepts and formulations [15].

\section{CONCLUSIONS}

Digital portable microscope auto design learning media is effective in improving the problem-solving ability of students 
[7] K. Jamuri and A. Doyan, "Pengaruh Model Pembelajaran Kooperatif STAD Berbasis Multi Media Interaktif Terhadap Pen guasaan Konsep Siswa pada Materi Termodinamika". Jurnal pendidikan Fisika Indonesia (2) 117-127. Jurnal Penelitian Pendidikan IPA (JPPIPA), 1(1): 123-134. 2015 .

[8] J. Dostal, "Theory of Problem Solving". Procedia Social and Behavioral Sciences. 174:2798-2805. 2015.

[9] S. Cilder and N. Sezen, "A Study on The Evaluation of Problem Solving Skills in Terms of Academic Success". Procedia Social and Behaviorial Sciences. 15: 2494-2499. 2011.

[10] T. Gok, "The General Assesment of Problem Solving Processes and Metacognition in Physics Education”. Eurasia Journal of Physics and Chemistry Education. 2(2):110122. 2010

[11] Zahriah, M. Hasan, and Z. Jalil, "Penerapan Pemecahan Masalah Model Polya untuk Meningkatkan Kemampuan Analisis dan Hasil Belajar pada Materi Vektor di SMAN 1 Darul Imarah". Jurnal Pendidikan Sains Indonesia, Vol.04, No.02, hlm. 151-161, 2016.

[12] Misbah, "Identifikasi Kemampuan Pemecahan Masalah Mahasiswa Pada Materi Dinamika Partikel". Jurnal Inovasi Dan Pembelajaran Fisika. 2016.

[13] E. Polytsinsky, L. Demenkova, and R.G. Kirbaslar, "Ways of Students Training Aimed at Analytical Skills Development while Solving Learning Tasks". Procedia Social and Behavioral Sciences.206:383-387. 2015.

[14] K. Karabacak, D. Nalbant, and P. Topcuoglu, "Examination of Teacher Candidate's Problem Solving Skills According to Several Variables". Procedia Social and Behavioral Sciences. 174:3063-3071. 2015.

[15] O. Kabil, "Philosophy in Physics Education". Procedia Social and Behavioral Sciences. 197:675-679. 2015. 